\title{
Efek Media Zoom Cloud Meeting Terhadap Keaktifan dan Hasil Belajar Bahasa Indonesia Siswa di Masa Pandemi Covid-19
}

\author{
Sri Rahayu B.*, Sulastriningsih Djumingin, Munirah \\ Program Pascasarjana Universitas Negeri Makassar \\ *Corresponding Author. Email: srirahayubadaruddin@gmail.com
}

\begin{abstract}
This study aims to analyze the effect of the zoom cloud meeting on the activeness and learning outcomes of Indonesian students during the Covid-19 pandemic. The population of this study amounted to 153 students. This study uses descriptive correlation method. The subjects of this study were students of class VIII.1 MTs Negeri Barru in Barru Regency, as many as 25 students. Sampling was done by using simple random sampling. The instrument used is a test in the form of multiple choice questions. The data analysis technique used was descriptive statistical analysis. The analysis carried out is a statistical test. The tests carried out consisted of the Shapirowilk normality test, and hypothesis testing with simple regression analysis. The results of this study indicate (1) The results of students' Indonesian learning before applying the zoom cloud meeting media have not been maximized, indicating that the average value obtained is $59.64 \%$. (2) The effect of the zoom cloud meeting media greatly helps students in activeness and learning outcomes of Indonesian shows that the average value obtained is 80.04\%. (3) After implementing the zoom cloud meeting media on the activities and results of learning Indonesian students during the Covid-19 pandemic and before applying the zoom cloud meeting media there was an effect on the process and results shown by the students.
\end{abstract}

\begin{abstract}
Abstrak: Penelitian ini bertujuan untuk menganalisis efek zoom cloud meeting terhadap keaktifan dan hasil belajar bahasa Indonesia siswa di masa pandemi Covid-19. Populasi penelitian ini berjumlah 153 siswa. Penelitian ini menggunakan metode descriptive correlation. Subjek penelitian ini adalah siswa kelas VIII.1 MTs Negeri Barru di Kabupaten Barru, yaitu sebanyak 25 siswa. Penarikan sampel dilakukan dengan menggunakan simple random sampling. Instrumen yang digunakan adalah tes dalam bentuk soal pilihan ganda.. Teknik analisis data yang digunakan analisis statistik deskriptif. Analisis yang dilakukan adalah uji statistik. Uji yang dilakukan terdiri atas uji normalitas Shapiro-wilk, dan uji hipotesis dengan analisis regresi sederhana. Hasil penelitian ini menunjukkan (1) Hasil belajar bahasa Indonesia siswa sebelum menerapkan media zoom cloud meeting belum maksimal menunjukkan bahwa nilai rata-rata yang diperoleh $59,64 \%$. (2) Efek media zoom cloud meeting sangat membantu siswa dalam keaktifan dan hasil belajar bahasa Indonesia menunjukkan bahwa nilai ratarata yang diperoleh $80,04 \%$. (3)Setelah menerapkan media zoom cloud meeting terhadap keaktifan dan hasil belajar bahasa Indonesia siswa di masa pandemi Covid-19 dan sebelum menerapkan media zoom cloud meeting terdapat efek pada proses dan hasil yang ditunjukkan oleh siswa.
\end{abstract}

\section{Article History}

Received: 07-05-2021

Revised: 30-06-2021

Accepted: 03-08-2021

Published: 07-09-2021

Key Words:

Zoom Cloud Meeting,

Activeness,

Learning Outcomes, Indonesian.

\section{Sejarah Artikel}

Diterima: 07-05-2021

Direvisi: 30-06-2021

Disetujui: 03-08-2021

Diterbitkan: 07-09-2021

\section{Kata Kunci:}

Zoom Cloud Meeting,

Keaktifan,

Hasil Belajar,

Bahasa Indonesia.

How to Cite: Rahayu B, S., Djumingin, S., \& Munirah, M. (2021). Efek Media Zoom Cloud Meeting Terhadap Keaktifan dan Hasil Belajar Bahasa Indonesia Siswa di Masa Pandemi Covid-19. Jurnal Kependidikan: Jurnal Hasil Penelitian dan Kajian Kepustakaan di Bidang Pendidikan, Pengajaran dan Pembelajaran, 7(3), 760-766. doi:https://doi.org/10.33394/jk.v7i3.3835 


\section{Pendahuluan}

Pendidikan merupakan suatu pengajaran dengan tujuan untuk mengembangkan kemampuan yang ada pada diri siswa, melalui proses belajar yang baik dan teratur. Menurut Sinaga \& Silaban (Andini, 2021) Pada proses pembelajaran siswa diharuskan untuk aktif dalam mencari, menemukan dan menggunakan pengetahuannya agar dapat memahami suatu konsep dengan atau tanpa bantuan guru selama proses belajar berlangsung. Hal inilah yang menjadi tugas guru dalam melaksanakan proses pembelajaran sebagai bagian dari proses pendidikan. Guru harus benar-benar menciptakan suatu pembelajaran yang efektif, karena guru "mengajar pada dasarnya merupakan suatu usaha untuk menciptakan kondisi atau sistem lingkungan yang mendukung dan memungkinkan untuk berlangsungnya proses belajar (Sardiman, 2011; Nur, 2021).

Banyak negara memutuskan menutup sekolah, perguruan tinggi maupun universitas, termasuk negara Indonesia (Syah, 2020). Dengan adanya virus Covid-19 ini membuat proses pembelajaran menjadi berubah dari yang tatap muka menjadi pembelajaran jarak jauh, tetapi dalam keadaan seperti ini guru masih tetap harus melaksanakan kewajibannya sebagai pengajar (Aulia, 2020). Pembelajaran jarak jauh merupakan sistem pembelajaran yang dilakukan dengan tidak bertatap muka langsung, tetapi menggunakan platform yang dapat membantu proses belajar mengajar yang dilakukan meskipun jarak jauh (Sofyana, 2019).

Zoom Meeting merupakan sebuah media pembelajaran menggunakan video. Zoom adalah aplikasi buatan miliarder, Eric Yuan, yang dirilis pada Januari 2013. Dalam aplikasi Zoom Meeting ini kita bisa berkomunikasi langsung dengan siapapun lewat video. Aplikasi ini menyediakan layanan konferensi jarak jauh dengan menggabungkan konferensi video, pertemuan online, obrolan, hingga kolaborasi seluler. Aplikasi ini banyak digunakan sebagai media komunikasi jarak jauh. Zoom memungkinkan pengguna melakukan meeting sampai 100 partisipan (Wilson, 2020).

Di sekolah MTs Negeri Barru Kabupaten Barru Provinsi Sulawesi Selatan, guru dan peserta didik menyelenggarakan pembelajaran jarak jauh sesuai intruksi mendikbud. Kegiatan pembelajaran dipandu oleh guru secara online melalui internet atau aplikasi pembelajaran yang tersedia. Perpanjangan masa darurat Covid-19 membuat pembelajaran jarak jauh semakin berlanjut. Pelaksanaan pembelajaran jarak jauh yang dilakukan mencangkup kegiatan penyampaian materi, penugasan dan evaluasi. Ada beberapa kendala yang terjadi dalam pembelajaran jarak jauh, seperti kendala pada koneksi internet dan kendala pada pembelajaran yang membuat jenuh. Pembelajaran jarak jauh dilakukan sesuai dengan jadwal pembelajaran seperti biasanya ketika tatap muka.

Dalam pencapaian tujuan pembelajaran yang merupakan salah satu komponen pembelajaran adalah metodologi pembelajaran. Akan tetapi, pada masa sekarang ini proses pembelajaran dilakukan di rumah serta pembelajaran tersebut bukan lagi sekadar interaksi guru dan siswa saja melainkan interaksi siswa dengan orang tua sangat dibutuhkan untuk mencapai suatu keberhasilan pembelajaran. Adapun upaya yang dilakukan untuk meningkatkan keaktifan dan hasil belajar siswa yaitu dengan menerapkan suatu model pembelajaran yang menarik dan siswa dapat aktif dalam proses pembelajaran tersebut.

Penelitian dari Yunitasari (2020) menyebutkan bahwa pembelajaran daring ini berpengaruh terhadap minat belajar siswa, dikarenakan siswa menjadi mudah bosan ketika pembelajaran daring berlangsung. Pembelajaran kurang menarik tidak seperti pembelajaran di kelas. Penelitian lain juga menyebutkan bahwa terdapat korelasi positif dan signifikan antara keterampilan metakognitif dan minat belajar terhadap hasil belajar siswa pada materi kesetimbangan kimia submateri pergeseran setimbangan baik secara parsial maupun simultan, dengan pengaruh variabel independen sebesar 76,6\% sementara 23,4\% dipengaruhi 
oleh aspek lain diluar variabel penelitian yang digunakan (Andini, 2021). Sedangkan penelitian ini memiliki kebaruan yakni menggunakan media Zoom Cloud Meeting dalam proses pembelajaran untuk mengetahui keaktifan dan hasil belajar bahasa indonesia siswa di masa pandemi Covid-19.

Dalam pencapaian tujuan pembelajaran yang merupakan salah satu komponen pembelajaran adalah media pembelajaran. Akan tetapi, pada masa sekarang ini proses pembelajaran dilakukan di rumah serta pembelajaran tersebut bukan lagi sekadar interaksi guru dan siswa saja melainkan interaksi siswa dengan orang tua sangat dibutuhkan untuk mencapai suatu keberhasilan pembelajaran. Adapun upaya yang dilakukan untuk meningkatkan keaktifan dan hasil belajar siswa yaitu dengan menerapkan media Zoom Cloud Meeting dalam proses pembelajaran tersebut.

Berdasarkan uraian diatas, penelitian ini bertujuan untuk menganalisis keaktifan dan hasil belajar bahasa Indonesia siswa di masa pandemi Covid-19 sebelum menggunakan media Zoom Cloud Meeting dan setelah menggunakan media Zoom Cloud Meeting.

\section{Metode Penelitian}

Metode penelitian ini menggunakan penelitian kuantitatif. Penelitian ini terdapat dua jenis variabel yaitu, variabel bebas (X) dan variabel terikat. Variabel bebas ialah media zoom cloud meeting yang disimbolkan sebagai (X). Variabel terikat ialah keaktifan dan hasil belajar bahasa Indonesia siswa di masa pandemi Covid-19 yang disimbolkan sebagai (Y). Desain penelitian pada penelitian ini adalah pre-eksperimen dengan menggunakan jenis penelitian One-Group Pretest-Postest. Desain One-Group Pretest Postest terdapat pretes dan postes, sehingga treatmen dapat dihitung dengan cara membandingkan nilai postes dengan pretes.

Populasi dalam penelitian ini adalah seluruh peserta didik kelas VIII MTs Negeri Barru pada tahun 2020/2021 yang terdiri atas 6 kelas dengan jumlah peserta didik 153 orang. Sampel yang di ambil dari populasi menggunakan teknik simple random sampling. Sampel yang di ambil dalam penelitian ini adalah satu kelompok belajar atau satu kelas dari populasi yang ada, sampel yang di ambil adalah kelas VIII.1 yang berjumlah 25 orang.Instrumen penelitian yang digunakan adalah tes. Data yang diperoleh dari hasil penelitian akan dianalisis dengan teknik analisis statistika yaitu: analisis statistik deskriptif dan analisis statistik inferensial.

\section{Hasil Penelitian dan Pembahasan}

Hasil penelitian menunjukkan bahwa tingkat keaktifan dan hasil belajar bahasa Indonesia sebelum menerapkan media zoom cloud meeting siswa di masa pandemi Covid-19 diklasifikasikan cukup berpengaruh dengan nilai 59,64. keaktifan dan hasil belajar bahasa Indonesia setelah menerapkan media zoom cloud meeting siswa di masa pandemi Covid-19 di klasifikasikan berpengaruh dengan nilai 80,04. Ada pengaruh yang signifikan antara keaktifan dan hasil belajar bahasa Indonesia sebelum dan setelah menerapkan media zoom cloud meeting siswa di masa pandemi covid-19 karena hasil perhitungan statistik inferensial jenis uji Paired Sample t-test di peroleh $\mathrm{T}_{\text {hitung }}>\mathrm{T}_{\text {tabel }}$ dengan nilai $-10.286>$ tt 1.710 .

Data diperoleh dari tes yang disebar pada 25 responden siswa kelas VIII MTs Negeri Barru, kemudian dianalisis dengan software SPSS 23. Data belajar bahasa Indonesia siswa diperoleh dari tes berisi soal pilihan ganda, keaktifan belajar diperoleh dari tes belajar, dan hasil belajar dari tes hasil belajar pada submateri bahasa Indonesia, sehingga dihasilkan data olah berikut ini. 


\section{Uji Normalitas}

Uji normalitas Shapiro-Wilk menunjukkan signifikasi keaktifan belajar bahasa indonesia sebesar 0,863, dan hasil belajar bahasa indonesia 0,073. Dapat dikatakan data hasil penelitian terdistribusi normal karena lebih besar dari $\alpha(0,05)$.

\section{Tabel 1. Tests of Normality}

\begin{tabular}{|c|c|c|}
\hline & ro-Wilk & $\mathrm{Sig}$ \\
\hline Netistic & DI & 863 \\
\hline .927 & 25 & .073 \\
\hline
\end{tabular}

\section{Uji Hipotesis}

Penelitian ini menerapkan hipotesis: ada efek media zoom cloud meeting terhadap keaktifan dan hasil belajar bahasa Indonesia siswa di masa pandemi Covid-19.

\section{Tabel 2. Model Summary}

\begin{tabular}{lr|r|r|r} 
Model & R & R Square & Adjusted R Square & \multicolumn{2}{c}{$\begin{array}{c}\text { Std. Error of the } \\
\text { Estimate }\end{array}$} \\
\hline 1 & $.540^{\mathrm{a}}$ & .292 & .261 & 6.830 \\
\hline
\end{tabular}

Tabel model summary menunjukkan nilai $\mathrm{R}$ yang merupakan simbol dari nilai koefisien regresi menunjukkan nilai $\mathrm{R}$ adalah 0,540 . Nilai ini dapat diinterpretasikan bahwa hubungan kedua variabel penelitian berada pada kategori berpengaruh. Melalui tabel ini diperoleh nilai $\mathrm{R}$ Square yang menunjukkan seberapa bagus modal regresi yang dibentuk oleh interaksi variabel bebas dan terikat. Nilai yang diperoleh adalah $29,2 \%$ yang dapat ditafsirkan bahwa variabel bebas X memiliki pengaruh kontribusi positif sebesar 29,2\% terhadap variabel $\mathrm{Y}$ dan $70.8 \%$ lainnya dipengaruhi oleh faktor-faktor diluar variabel $\mathrm{X}$.

Pengaruh variabel independen terhadap variabel dependen secara varsial dapat dianalisis dengan uji T.

\begin{tabular}{|c|c|c|c|c|c|c|}
\hline \multirow{3}{*}{\multicolumn{2}{|c|}{ Model }} & \multicolumn{3}{|c|}{ Tabel 3. Coefficients ${ }^{a}$} & \multirow[b]{3}{*}{$\mathrm{T}$} & \multirow[b]{3}{*}{ Sig. } \\
\hline & & \multicolumn{2}{|c|}{$\begin{array}{l}\text { Unstandardized } \\
\text { Coefficients }\end{array}$} & \multirow{2}{*}{$\begin{array}{l}\text { Standardized } \\
\text { Coefficients } \\
\text { Beta }\end{array}$} & & \\
\hline & & $\mathrm{B}$ & Std. Error & & & \\
\hline \multirow[t]{2}{*}{1} & (Constant) & 58.003 & 7.288 & & 7.959 & .000 \\
\hline & Pretest & .370 & .120 & .540 & 3.078 & .005 \\
\hline
\end{tabular}

Pada tabel koefesien pada kolom B pada konstanta (a) adalah 58,003 sedang nilai pada kategori 0,543 sehingga persamaan regresinya sebagai berikut: $\mathrm{Y}=58,003+0,370 \mathrm{X} 1$.

Koefesien B dinamakan arah regresi dan menyatakan sebesar satu-satuan, perubahan ini merupakan pertambahan positif sehingga, persamaan tersebut diartikan sebagai berikut : $\mathrm{H}_{0}=$ tidak ada pengaruh yang signifikan variabel $\mathrm{X}$ (media zoom cloud meeting) $\mathrm{H}_{1}=$ ada pengaruh yang signifikan variabel $\mathrm{X}$ (media zoom cloud meeting) terhadap keaktifan dan hasil belajar bahasa Indonesia (Y).

Adapun signifikan variabel terikat $0,000<0,05$ artinya variabel bebas berpengaruh signifikan terhadap variabel terikat. Dengan kata lain $\mathrm{H}_{1}$ diterima berarti ada pengaruh yang signifikan variabel $\mathrm{X}$ (media zoom cloud meeting) terhadap terhadap keaktifan dan hasil belajar bahasa Indonesia $(\mathrm{Y})$. Jadi, hipotesis $\left(\mathrm{H}_{0}\right)$ dan hipotesis satu $\left(\mathrm{H}_{1}\right)$ diterima. Hasil analisis tersebut menunjukkan bahwa terdapat perbedaan yang signifikan antara nilai pretest dan nilai posttest terhadap keaktifan dan hasil belajar bahasa Indonesia siswa di masa 
pandemi Covid-19. Pengaruh variabel independen terhadap variabel dependen secara simultan dapat dianalisis dengan uji $\mathrm{F}$

\begin{tabular}{|c|c|c|c|c|c|c|}
\hline \multirow[b]{2}{*}{ Model } & & \multicolumn{3}{|c|}{ Tabel 4. ANOVA ${ }^{\mathrm{a}}$} & \multirow[b]{2}{*}{$\mathrm{F}$} & \multirow[b]{2}{*}{ Sig. } \\
\hline & & $\begin{array}{l}\text { Sum of } \\
\text { Squares }\end{array}$ & df & Mean Square & & \\
\hline \multirow[t]{3}{*}{1} & Regression & 442.058 & 1 & 442.058 & 9.476 & $.005^{\mathrm{b}}$ \\
\hline & Residual & 1072.902 & 23 & 46.648 & & \\
\hline & Total & 1514.960 & 24 & & & \\
\hline
\end{tabular}

Berdasarkan tabel ANOVA, berdasarkan uji $\mathrm{F}$ atau uji nilai signifikansi (sig). cara yang paling mudah dengan uji sig. dengan ketentuan, jika nilai sig. > 0,05, maka model regresi adalah linear, dan berlaku sebaliknya. Berdasarkan tabel ketiga, diperoleh nilai sig. $=0,005$ yang berarti > kriteria signifikan $(0,05)$, dengan demikian model persamaan regresi berdasarkan data penelitian adalah signifikan artinya, model regresi linear memenuhi kriteria linearitas.

Berdasarkan analisis yang telah dilakukan, dapat dijelaskan bahwa keaktifan berpengaruh positif dan signifikan terhadap hasil belajar bahasa Indonesia siswa, hal ini sependapat dengan penelitian dari penelitian dari Yunitasari (2020) menyebutkan bahwa pembelajaran daring ini berpengaruh terhadap minat belajar siswa, dikarenakan siswa menjadi mudah bosan ketika pembelajaran daring berlangsung. Pembelajaran kurang menarik tidak seperti pembelajaran di kelas. Penelitian lain juga menyebutkan bahwa terdapat korelasi positif dan signifikan antara keterampilan metakognitif dan minat belajar terhadap hasil belajar siswa pada materi kesetimbangan kimia submateri pergeseran setimbangan baik secara parsial maupun simultan, dengan pengaruh variabel independen sebesar 76,6\% sementara 23,4\% dipengaruhi oleh aspek lain diluar variabel penelitian yang digunakan (Andini, 2021).

\section{Kesimpulan}

Berdasarkan hasil penelitian dan pembahasan dapat disimpulkan bahwa tingkat keaktifan dan hasil belajar bahasa Indonesia sebelum menerapkan media zoom cloud meeting siswa di masa pandemi Covid-19 di klasifikasikan cukup berpengaruh dengan nilai 59,64. Keaktifan dan hasil belajar bahasa Indonesia setelah menerapkan media zoom cloud meeting siswa di masa pandemi Covid-19 di klasifikasikan berpengaruh dengan nilai 80,04. Ada pengaruh yang signifikan antara keaktifan dan hasil belajar bahasa Indonesia sebelum dan setelah menerapkan media zoom cloud meeting siswa di masa pandemi covid-19 karena hasil perhitungan statistik inferensial jenis uji Paired Sample t-test di peroleh $T_{\text {hitung }}>T_{\text {tabel }}$ dengan nilai $-10.286>$ tt 1.710 dan hasil uji regresi nilai signifikansi lebih kecil dari nilai probabilitas bahwa penggunaan media zoom cloud meeting berpengaruh terhadap Keaktifan dan hasil belajar bahasa Indonesia di masa pandemi Covid-19.

\section{Saran}

Saran yang dapat disampaikan berdasarkan hasil penelitian ini antara lain adalah; (1) Bagi guru agar dapat menerapkan proses pembelajaran yang menekankan pada aplikasi media zoom cloud meeting terhadap keaktifan dan hasil belajar siswa di masa pandemi. (2) Bagi siswa agar membiasakan diri selalu mempelajari materi-materi lewat buku dan diharapkan untuk dapat memahami cara belajar yang sesuai, lebih aktif selama pembelajaran dan meningkatkan hasil belajarnya. 


\section{Daftar Pustaka}

Agustina, Sofiah, Eka. (2020). Pembelajaran Memahami Teks. Aksara: Jurnal Bahasa dan Sastra 18 (1)

Andini, L., \& Azizah, U. (2021). Analisis Korelasi Keterampilan Metakognitif dan Minat Belajar terhadap Hasil Belajar Siswa pada Materi Kesetimbangan Kimia. Jurnal Kependidikan: Jurnal Hasil Penelitian dan Kajian Kepustakaan di Bidang Pendidikan, Pengajaran dan Pembelajaran, 7(2), 472-480. doi:https://doi.org/10.33394/jk.v7i2.3327

Aulia, S. (2020). Pembelajaran Daring Pada Masa Pandemi. 20 Juli. https://www.suara.com/yoursay/2020/07/20/175556/pembelajaran-daring-pada-masapandemi

Dewojati, Cahyaningrum. (2012). Drama, Sejarah, Teori, dan Penerapannya. Yogyakarta: Javakarsa Media.

Elfiza, Mira. (2017). Hubungan Keterampilan Membaca Pemahaman Naskah Drama dengan Keterampilan Menulis Naskah Drama Siswa Kelas VIII SMP Negeri 13 Padang. Jurnal Pendidikan Bahasa dan Sastra Indonesia, 6(2), 208-213.

Endraswara, S. (2014). Metode Pembelajaran Drama Apresiasi, Ekspresi, dan Pengkajian. CAPS Center of Academic Publishing Service). Yogyakarta.

Isnatun, Siti, dan Farida, Umi. 2013. Mahir Berbahasa Indonesia. Bogor: Yudistira.

Kemendikbud. (2014). Buku Guru Bahasa Indonesia Wahana Pengetahuan SMP/MTs Kelas VIII. Jakarta: Kementerian Pendidikan dan Kebudayaan. . (2014). Buku Siswa Bahasa Indonesia Wahana Pengetahuan SMP/MTs Kelas VIII. Jakarta: Kementerian Pendidikan dan Kebudayaan.

Keraf, Gorys (2011). Argumentasi dan Narasi. Jakarta: Gramedia.

Kosasih, E. (2014). Strategi Belajar dan Pembelajaran Implementasi Kurikulum 2013. Bandung: Yrama Widya

Milatul, Iva. (2020). Pembelajaran Menyimak Naskah Drama Dengan Model Pembelajaran Bermain Peran Pada Siswa Kelas XI SMK PGRI 3 Bojonegoro. Jurnal Sains Sosio Humaniora. 4 (2), 603-612.

Mulyadi, Yadi dkk. (2016). Intisari Tata Bahasa Indonesia untuk SMP dan SMA. Bandung; Yrama Widya.

Nurgiyantoro, Burhan. (2010). Penilaian Pembelajaran Bahasa. Yogyakarta: BPFE.

Priasti, S., \& Suyatno, S. (2021). Penerapan Pendidikan Karakter Gemar Membaca Melalui Program Literasi di Sekolah Dasar. Jurnal Kependidikan: Jurnal Hasil Penelitian dan Kajian Kepustakaan di Bidang Pendidikan, Pengajaran dan Pembelajaran, 7(2), 395407. doi:https://doi.org/10.33394/jk.v7i2.3211

Prawiyogi, Anggy Giri, dkk. 2020. Efektifitas Pembelajaran Jarak Jauh Terhadap Pembelajaran Siswa Di SDIT Cendekia Purwakarta. JPD: Jurnal Pendidikan Dasar. Hal 94-95

Ramadania, Fajarika. (2016). Konsep Bahasa Berbasis Teks Pada Buku Ajar Kurikulum 2013. Stilistika: Jurnal Bahasa, Sastra, dan pengajarannya. 1(2), 228-229.

Resmini, Novi. (2014). Prinsip Dasar Pembelajaran Bahasa Indonesia. Universitas Pendidikan Indonesia. Universitas Pendidikan Indonesia (Prinsip_Dasar_Pembelajaran_Bahasa_Indonesia.pdf, Diakses 03 Maret 2017).

Saragih, Amrin. 2016. Pembelajaran Kurikulum Berbasis Teks dalam Kurikulum 2013. Medan Makna, 14(2), Hal, 197-198 
Sofyana \& Abdul. (2019). Pembelajaran Daring Kombinasi Berbasis Whatsapp Pada Kelas Karyawan Prodi Teknik Informatika. Jurnal nasional pendidikan teknik informatika, 8 (1), 82.

Sulistyana. (2020). Pelaksanaan Pembelajaran Jarak Jauh Pada Level Pendidikan Anak Usia Dini. Universitas Negeri Maulana Malik Ibrahim Malang.

Syah, R. H. (2020). Dampak Covid-19 pada Pendidikan di Indonesia: Sekolah, Keterampilan, dan Proses Pembelajaran. SALAM: Jurnal Sosial Dan Budaya Syar-I, 7(5). https://doi.org/10.15408/sjsbs.v7i5.15314

Waluyo, Budi. (2018). Bahasa dan sastra Indonesia untuk kelas VIII SMP dan MTs. Solo: Tiga Serangkai Pustaka Mandiri.

Widyahening, Evi Tri., dkk. (2012). Kajian Drama: Teori \& Implementasi. Surakarta: Cakrawala Media.

Wilson, A. (2020). Penerapan Metode Pembelajaran Daring (Online) Melalui Aplikasi Berbasis Android Saat Pandemi Global. SAP (Susunan ArtikelPendidikan), 5(1), 7. http://dx.doi.org/10.30998/sap.v5i1.6511

Wiyanto, Asul. (2012). Terampil Bermain Drama. Jakarta: Grasindo.

Zoom Video Communications Inc. (2016). Zoom Global Infrastructure and Security Guide.pdf. https://zoom.com.cn/docs/doc/Zoom_Global_Infrastructure.pdf 